\title{
HUBUNGAN PENGUASAAN KOSAKATA DENGAN KESALAHAN DIKSI DALAM KALIMAT BAHASA INDONESIA MAHASISWA BIPA LEVEL AKADEMIK
}

\author{
Mokh. Yahya, Andayani, Kundharu Saddhono \\ Email: myahyabtg99@gmail.com
}

\author{
Prodi Magister Pendidikan Bahasa Indonesia, Fakultas Keguruan dan Ilmu \\ Pendidikan, Universitas Sebelas Maret, Indonesia
}

\begin{abstract}
This study aims to explain the relationship of vocabulary mastery with errors diction in the Indonesian language sentence BIPA academic level. This research was conducted at Language Unit of Sebelas Maret University, Surakarta, Indonesia with subject of students who are following the learning of Indonesian Language for Foreign Speakers of Darmasiswa Program 2016-2017. The approach used in this study is descriptive qualitative approach in the form of case study. This study focused on the types of diction errors and their relation to the mastery of vocabulary held by BIPA students. This study has shown that the types of errors dictions in the BIPA sentence include 1) the choice of dictions is less or inappropriately, (2) misuse of active and passive verbs, (3) use of foreign terms, (4) use of less pronouns or improper usage, (5) improper use of conjunctions, (6) word overload or word repeatability, (7) non-standard wording, (8) inaccessibility, (9) inappropriate use of prepositions, and (10) upside down. Low vocabulary mastery is related to the number of mistakes made by the students of BIPA. The more vocabulary that is mastered by the students, the better the ability to choose diction to be written into sentences.
\end{abstract}

keywords: relation of lexicon mastery with diction errors, Indonesian sentence, BIPA student.

\section{Abstrak}

Penelitian ini bertujuan untuk menjelaskan hubungan penguasaan kosakata dengan kesalahan diksi dalam kalimat bahasa Indonesia mahasiswa BIPA level akademik. Penelitian ini dilakukan di UPT Bahasa Universitas Sebelas Maret, Surakarta, Indonesia dengan subjek mahasiswa yang sedang mengikuti pembelajaran Bahasa Indonesia bagi Penutur AsingProgram Darmasiswa 2016-2017. Pendekatan yang digunakan dalam penelitian ini adalah pendekatan kualitatif deskriptif dalam bentuk studi kasus. Penelitian difokuskan pada tipe-tipe kesalahan diksi dan hubungannya dengan penguasaan kosakata yang dimiliki oleh mahasiswa BIPA. Penelitian menunjukkan bahwa tipe-tipe kesalahan diksi dalam kalimat BIPA di antaranya yaitu 1) pemilihan diksi yang kurang atau tidak tepat, (2) kesalahan penggunaan verba aktif dan pasif, (3)penggunaan istilah asing, (4) penggunaan kata ganti yang kurang atau tidak tepat, (5) penggunaan konjungsi yang tidak tepat, (6) kelebihan kata atau pengulangan kata, (7)penggunaan kata tidak baku, (8) ketidakparalelan, (9) penggunaan preposisi yang tidak tepat, dan (10)susunan frasa yang terbalik. Penguasaan kosakata yang rendah berhubungan dengan banyaknya kesalahan diksi yang dilakukan oleh mahasiswa BIPA. Makin banyak kosakata yang dikuasai oleh mahasiswa, makin baik pula kemampuannya dalam memilih diksi untuk dituliskan menjadi kalimat.

kata kunci: hubungan penguasaan kosakata dengan kesalahan diksi, kalimat bahasa indonesia, mahasiswa bipa

\section{PENDAHULUAN}

Program Bahasa Indonesia bagi Penutur Asing (BIPA) adalah salah satu upaya untuk menginternasionalisasi bahasa Indonesia kepada dunia. BIPA kini sudah diminati banyak warga negara asing. Berdasarkan data Depdiknas, tercatat ada 219 perguruan tinggi/lembaga di 40 negara yang telah menyelanggarakan program ini. Negara-negara penyelenggara program ini antara lain: Australia,
Austria, Canada, Belanda, Polandia, China, Cekoslovakia, Denmark, Mesir, Perancis, Jerman, India, Itali, Jepang, Malaysia, New Zealand, Norwegia, Papua Nugini, Rusia, Saudi Arabia, Singapura, Korea Selatan, Suriname, Swedia, Switzerland, Filipina, Inggris, Amerika, Vatikan, Vietnam, dan Tahiland (Kusmiatun, 2016:10). Pembelajaran BIPA mempunyai tiga tingkatan, yaitu tingkat dasar, madya, dan mahir. Tingkatan tersebut muncul berkaitan 
erat dengan tujuan pembelajar asing mengikuti pembelajaran BIPA. Tujuan para penutur asing belajar bahasa Indonesia disesuaikan dengan konteksnya. Konteks di sini adalah keperluan atau kebutuhan dari penutur asing tersebut untuk belajar bahasa Indonesia. Ada banyak tujuan para pembelajar BIPA saat mereka belajar bahasa Indonesia. Ada pembelajar BIPA yang belajar bahasa Indonesia dengan tujuan mampu berkomunikasi sehari-hari. Ada pula yang tujuannya lebih pada fokus dalam pekerjaan atau bidang yang digelutinya (orientasi pada pekerjaan). Bagi wisatawan asing, bahasa Indonesia yang dibutuhkan adalah bahasa Indonesia untuk jalanjalan atau rekreasi. Tujuan lain dalam belajar bahasa Indonesia adalah tujuan akademik.

Iskandarwassid dan Sunendar (2013:283) menentukan tingkatan pembelajar BIPA yaitu tingkat pemula, tingkat menengah, dan tingkat lanjut. Sependapat dengan Iskandarwassid dan Sunendar, Kusmiatun (2016:5) menjelaskan tingkatan BIPA berdasarkan kemampuan pembelajarnya, yaitu BIPA level dasar (elementary), level menengah (intermediate), dan level lanjut (advance). Level dasar yaitu pembelajar BIPA yang masih pemula. Level menengah yaitu pembelajar yang masuk kategori lebih tinggi dari level dasar. Level lanjut adalah pembelajar yang berada pada jenjang paling atas dalam BIPA.

Belajar berbahasa tidak sama
dengan belajar tentang bahasa.
Belajar berbahasa merujuk
kepadabelajar empat keterampilan
berbahasa: menyimak, berbicara,
membaca, dan menulis. Dalam
belajar empat keterampilan tersebut,

tentunya dibutuhkan pengetahuan tentang fonologi, morfologi, sintaksis, dan semantik bahasa yang sedang dipelajari (Muliastuti, 2010).

Penelitian ini berfokus pada kesalahan diksi yang dilakukan oleh mahasiswa BIPA level akademik. Diksi adalah salah satu kajian yang terdapat dalam bidang sintaksis. Dengan menguasai penggunaan diksi, mahasiswa BIPA akan mampu menyusun kalimat dalam bahasa Indonesia dengan baik. Begitu juga sebaliknya, apabila mahasiswa kurang mampu menggunakan diksi, ia juga akan banyak melakukan kesalahan diksi dalam kalimat yang ditulisnya.

\section{KAJIAN TEORI}

BIPA merupakan pembelajaran bahasa Indonesia yang subjeknya adalah pembelajar asing. BIPA dipandang lebih pada faktor pembelajarnya. Orang-orang yang menjadi subjek pembelajaran BIPA adalah orang asing, bukan penutur bahasa Indonesia (Kusmiatun, 2016:1).

Proses pembelajaran Bahasa Indonesia bagi Penutur Asing yang disebut dengan BIPA hampir sama seperti proses pembelajaran pada umumnya, yakni memiliki sebuah sistem di mana keberhasilan belajar siswa/mahasiswa BIPA ditentukan oleh berbagai faktor pendukung. Sanjaya (2006: 57) menjelaskan bahwa untuk menentukan apakah siswa telah belajar atau belum dapat dilihat dengan cara membandingkan kondisi sebelum dan sesudah proses pembelajaran.

Pilihan kata atau diksi pada dasarnya adalah hasil dari upayamemilih kata tertentu untuk dipakai dalam membuat kalimat, 
alinea, atau wacana (Lamuddin Finoza 2010:129).Keraf (2009:24) menyatakan tiga hal utama mengenai diksi. Ketiga hal tersebut yaitu (1) pemilihan kata atau diksi mencakup pengertian kata-kata mana yang akan dipakai untuk menyampaikan suatu gagasan, bagaimana membentuk pengelompokan kata-kata yang tepat atau menggunakan ungkapanungkapan yang tepat, dan gaya mana yang paling baik digunakan dalam situasi, (2) pilihan kata atau diksi adalah kemampuan membedakan secara tepat nuansa-nuansa makna dari gagasan yang ingin disampaikan, dan kemampuan untuk menemukan bentuk yang sesuai (cocok) dengan situasi dan nilai rasa yang dimiliki kelompok masyarakat pendengar, dan (3) pilihan kata yang tepat dan sesuai hanya dimungkinkan oleh penguasaan sejumlah besar kosakata atau perbendaharaan kata bahasa itu. Adapun yang dimaksud perbendaharaan kata atau kosakata suatu bahasa adalah keseluruhan kata yang dimiliki oleh sebuah bahasa.

Kesalahan berbahasa adalah bagian dari sebuah percakapan yang menyimpang dari beberapa norma atau aturan penggunaan bahasa yang dipilih(Dulay, Burt, dan Krashen, 1982:277). Kesalahan berbahasa adalah penyimpangan yang tampak pada tata bahasa penutur asli yang mencerminkan kompetensinya dalam berbahasa (Brown, 1994:205).

Kesalahan diksi adalah salah satu bagian kajian kesalahan berbahasa dalam tataran sintaksis.Kesalahan tersebut dapat diketahui apabila diksi yang digunakan tidak memenuhi tiga syarat berikut: (1) tepat (mengungkapkan gagasan secara cermat), (2) benar (sesuai dengan kaidah kebehasaan), dan (3) lazim pemakaiannya (Pusat Bahasa, 2006:41).

Kosakata adalah perbendaharaan kata. Penguasaan kosakata adalah kegiatan untuk menguasai, memahami, dan menggunakan kata-kata dalam suatu bahasa baik secara tulisan maupun lisan (Elviza, Emidar, dan Noveria, 2013:469). Penguasaan kosakata merupakan salah satu komponen yang penting dari kemampuan bahasa seperti membaca dan berbicara (Schmitt dan McCarthy 1997:6). Furqon (2013:71) menerangkan penguasaan kosakata secara lebih spesifik. Menurutnya, unsur penguasaan kosakata tidak hanya mengetahui kata-kata dan maknanya, tetapi juga mengetahui tentang bagaimana kata-kata terdengar dan bagaimana kata-kata yang digunakan dalam konteks. Pusvita (2017:27) dalam penelitian tesisnya juga mengungkapkan bahwa penguasaan kosakata adalah kemampuan pelajar dalam menguasaibanyak perbendaharaan kata sebagai dasar untuk mengekspresikan bahasa denganbaik.

\section{METODE PENELITIAN}

Penelitian ini dilaksanakan di UPT Bahasa Universitas Sebelas Maret, Surakarta, Indonesia. Subjek penelitian dalam penelitian ini adalah 11 mahasiswa yang berasal dari berbagai negara yang sedang mengikuti Pembelajaran BIPA level akademik Program Darmasiswa. Penelitian ini merupakan jenis penelitian kualitatif yang berupa studi kasus.Studi kasus merupakan penelitian yang dilakukan untuk mengungkap suatu keadaan secara mendalam, intensif, baik mengenai perseorangan, secara individual, 
maupun kelompok, dan lembaga masyarakat (Mahmud, 2011:102).Strategi di dalam penelitian ini adalah studi kasus tunggal.Penelitian ini disebut studi kasus tunggal karena penelitian ini fokus pada satu hal, yakni kesalahan diksidalam kalimat bahasa Indonesia mahasiswa BIPA yang sedang belajar di UPT Bahasa Universitas Sebelas Maret Surakarta. Kalimat yang diteliti berwujud tulisan yang merupakan produk pembelajaran. Yule (2014: 318) menuturkan bahwa tulisan ialah representasi simbolik bahasa melalui penggunaan simbolsimbol grafis. Tulisan harus dipelajari melalui usaha sadar terus-menerus.

Data di dalam penelitian ini berupa sejumlah informasi yang berkaitan dengan kajian kesalahan diksi kalimat bahasa Indonesia mahasiswa BIPA di UPT Bahasa Universitas Sebelas Maret. Kendalakendala dalam pembelajaran sintaksis termasuk dalam topik informasi dalam penelitian ini. Jenis sumber data di dalam penelitian ini diperoleh dari informan atau narasumber dan dokumen berupa hasil karangan mahasiswa BIPA. Penelitian ini menggunakan teknik pengumpulan data dengan wawancaradan analisis dokumen.Pengujian validitas data dalam penelitian ini dilakukan dengan cara triangulasi. Peneliti menggunakan triangulasi sumber data, metode, dan teori.

Teknik analisis data di dalam penelitian ini menggunakan teknik analisis interaktif. Analisis adalah proses menyusun data agar dapat ditafsirkan (Nasution, 1992:126). Menurut Sutopo (2016:114-116) analisis data dengan menggunakan teknik analisis interaktif terdiri atas tiga bagian setelah adanya

56 | Jurnal Kredo Vol. 1 No. 2 April 2018 pengumpulan data, yakni reduksi data, sajian data, dan penarikan simpulan dan verifikasi.

\section{HASIL DAN PEMBAHASAN}

Kesalahan diksi merupakan salah satu bentuk-bentuk kesalahan berbahasa dalam bidang sintaksis di samping kesalahan ejaan dan kesalahan-kesalahan lainnya.

Dalam menulis kalimat diksi yang digunakan perlu diperhatikan. Hal itu berkaitan dengan maksud yang hendak disampaikan oleh penulis kepada pembaca. Apabila diksi yang digunkan tidak sesuai dengan situasi dan kondisi, dapat mengakibatkan pembaca salah pengertian dalam memahami maksud si penulis. Dengan begitu, diksi yang digunakan dalam sebuah tulisan harus tepat agar maksud penulis dapat dipahami dengan cermat oleh pembaca. Dalam penelitian ini dipaparkan bentuk-bentuk kesalahan penggunaan diksi dalam kalimat bahasa Indonesia mahasiswa BIPA.

Pemilihan diksi berpengaruh pada keefektifan kalimat. Sumarwati (2015:109) bahwa pilihan kata menunjuk pada pengertian penggunaan suatu kata, dari sejumlah besar kata yang dikuasai penulis. Biasanya orang membuka kamus untuk mengetahui arti sebuah kata, cara menuliskannya, atau cara melafalkannya. Akan tetapi, banyak juga yang menginginkan lebih dari itu. Mereka ingin menemukan kata tertentu untuk mengetahui pemakaiannya secara tepat. Pilihan kata yang "terbaik" adalah yang memenuhi syarat (1) tepat (mengungkapkan gagasan secara cermat), (2) benar (sesuai dengan kaidah kebahasaan), dan (3) lazim 
pemakaiannya (Pusat Bahasa, 2006:41).

Kesalahan diksi dapat dijabarkan menjadi beberapa jenis. Menurut Arifin dan Tasai (2010:3953), kesalahan penggunaan diksi dijabarkan menjadi 10 jenis, yaitu (1) penanggalan awalan meng-, (2) penganggalan awalan ber-, (3) peluluhan bunyi $/ c /$, (4) penyengauan kata dasar, (5) bunyi $/ \mathrm{s} /, / \mathrm{k} /, / \mathrm{p} / \mathrm{/} / \mathrm{t} /$ yang berimbuhan meng-/peng-, (6) awalan ke- yang keliru, (7) pemakaian akhiran -ir, (8) padanan yang tidak serasi, (9) pemakaian kata depan di, ke, dari, bagi, pada, daripada, dan terhadap, (10) penggunaan kata kesimpulan, keputusan, penalaran, dan pemukiman, (11) penggunaan kata yang hemat, (12) bentuk jamak dalam bahasa Indonesia, dan (13) penggunaan di mana, yang mana, dan hal mana.

Tipe-tipe Kesalahan Diksi dalam Kalimat Mahasiswa BIPA

Kesalahan diksi dilakukan oleh seluruh mahasiswa BIPA yang berjumlah 11. Kesalahan-kesalahan tersebut dipaparkan sebagai berikut.

Ketidaktepatan pemilihan kata yang pertama dilakukan oleh mahasiswa dari Filipina bernama Leizel. Kesalahan tersebut ditemukan pada kalimat berikut.

(a) Membuat pendaftaran online.

(b) Mudah untuk memasak ketika Anda lapar.

Pemilihan diksi membuat pada kalimat (a) tidak tepat.Kata yang tepat akan membantu seseorang mengungkapkan dengan tepat apa yang ingin disampaikannya, baik lisan maupun tulisan. Di samping itu, pemilihan kata itu harus pula sesuai dengan situasi dan tempat penggunaan kata-kata itu (Arifin dan Tasai, 2010:28).Sebaiknya, dalam kalimat tersebut digunakan diksi melakukan karena objek kalimat tersebut pendaftaran.

Dalam kalimat (b) terdapat diksi memasak. Diksi tersebut tidak tepat digunakan dalam kalimat tersebut karena didahului dengan kata depan untuk. Kalimat tersebut termasuk kalimat pasif sehingga kata kerja (verba) yang digunakan juga harus berbentuk pasif. Verba yang tepat digunakan dalam kalimat tersebut adalah dimasak, bukan memasak.

Sekurang-kurangnya kalimat dalam ragam resmi, baik lisan maupun tulisan, harus memiliki subjek (S) dan predikat (P).Kalau tidak memiliki unsur subjek dan unsur predikat, pernyataan itu bukanlah kalimat (Arifin dan Tasai, 2010:66).Kalimat (e) belum memliki subjek.Subjek bisa ditambahkan sesuai dengan konteksnya.Konteks karangan dalam kalimat tersebut adalah memasak Indomie.

Kalimat (a) dan (b) tersebut dapat diperbaiki menjadi kalimat berikut.

(a.1) Melakukan pendaftaran online.

(b.1) Indomie mudah untuk dimasak ketika Anda lapar.

Ketidaktepatan pemilihan kata yang kedua dilakukan oleh mahasiswa dari Korea Selatan, yaitu Jeon Hyo Bin.

Dalam karangan bahasa Indonesia Hyo Bin terdapat tiga kesalahan diksi, yaknipenggunaan kata ganti, penggunakan istilah asing, dan pemilihan diksi yang tidak tepat. 
Kesalahan tersebut dapat dilihat pada klausa berikut.

(c)warna badan itu putih

(d) warna screen hitam

(e)bentuknya persegi panjang tapi di pojok bengkok

Sebaiknya kata ganti itudalam klausa (c) diganti dengan nyadan kata badan diganti dengan gagang karena konteksnya adalah bagian-bagian gawai atau ponsel.Klausa (c) dapat diperbaiki menjadi warna gagangnya putih.Agarlebih efektif, diksi warna pada klausa tersebutbisa dihilangkan.

Diksi screen pada klausa (d) tidak tepat digunakan karena masih dalam bentuk bahasa asing, Inggris. Dalam bahasa Indonesia diksi screen diterjemahkan menjadi layar. Seperti halnya klausa (c), diksi warna pada klausa (d), sebaiknya, dihilangkan.

Kesalahan diksi yang terdapat pada klausa (e) berupa penggunaan konjungsi yang tidak baku dan diksi yang tidak tepat. Penggunaan konjungsi tapi dalam klausa tersebut sudah tepat karena bermakna perlawanan, tetapi konjungsi tersebut tidak baku. Konjungsi tapi sebaiknya diganti dengan tetapi. Selanjutnya, kata bengkokjuga kurang tepat digunakan dalam klausa tersebut. Sebaiknya, kata bengkok diganti dengan kata melengkung.

Perbaikan klausa (c), (d), dan

(e) sebagai berikut.

\section{(c.l) gagangnya putih}

(d.1) layarnya hitam

(e.1)bentuknya persegi panjang,tetapi di pojok melengkung

58 | Jurnal Kredo Vol. 1 No. 2 April 2018
Ketidaktepatan pemilihan kata yang ketiga dilakukan oleh mahasiswa dari Jepang bernama Koharu. Kesalahan tersebut ditemukan pada kalimat berikut.

(f) Dan juga Apakah kalian ada kesempatan yang bisa lihat acara lain?

Konjungsi dan tidak tepat digunakan untuk mengawali kalimat karena bukan konjungsi antarkalimat. Konjungsi dan dan kata jugabisa dihilangkan agar kalimat (f) menjadi efektif. Selain itu, kata ada pada kalimat (f) juga kurang tepat digunakan. Dalam Kamus Besar Bahasa Indonesia kata ada bisa bermakna mempunyai. Namun, dalam konteks tertulis kata ada tidak lazim digunakan untuk menggantikan kata mempunyai. Penggunaan kata lihat juga kurang tepat. Dalam kalimat aktif kata tersebut perlu mendapat awalan meng- sehingga menjadi kata verba melihat. Agar lebih tepat, verba melihat bisa diganti menyaksikan. Perbaikan kalimat (f) sebagai berikut.

(f.1) Apakah kalian mempunyai kesempatan yang bisa menyaksikan acara lain?

Ketidaktepatan pemilihan kata yang keempat dilakukan oleh mahasiswa dari Vietnam bernama Alisa. Kesalahan tersebut ditemukan pada kalimat berikut.

(g) Makanan cepat saji adalah makanan langsung menjadi pembelian seperti makanan di Mc. Donald, di KFC, di Pizza Hut. 
(h) Menurut data-data kepolisian RI pada tahun 1980 ditemukan fakta bahwa 50\% kecelakaan yang menimbulkan korban jiwa dari pengendara sepeda motor disebabkan oleh luka kepala.

(i) Dia mempunyai satu tanda lalat yang besar di alis.

(j) Ibu saya tidak bagus tentang masak makanan tapi dia sangat rajin dan bussiness yang pintar.

Kalimat (g) tidak efektif karena diksi yang digunakan kurang tepat. Sebaiknya, makanan langsung menjadi pembelian diubah menjadi makanan langsung jadi dan dibeli. Selain itu, penggunaan kata depan $d i$ pada kalimat tersebut tidak perlu diulang, cukup sekali.

Penggunaan diksi menurut pada kalimat (h) kurang tepat karena objek yang dirujuk oleh kata tersebut berupa benda bukan manusia. Diksi yang tepat untuk menggantinya yaitu berdasarkan. Agar lebih efektif, perlu ditambahkan tanda koma setelah tahun 1980 dan susunan kalimat (h) juga bisa diubah.

Pada kalimat (i) ditemukan diksi tanda lalat. Dalam bahasa Indonesia diksi tanda lalat bisa diganti tahi lalat. Selain itu, kata ganti dia kurang tepat digunakan kareana subjek yang digantikan adalah ibu. Sebaiknya, kata ganti yang digunakan adalah beliau karena lebih sopan.

Adapun pada kalimat (j), dijumpai kata bagus untuk menyifatkan keterampilan memasak dan kata bussiness untuk menerjemahkan kata pebisnis. Diksi yang tepat untuk menggantinya adalah pandai dan pebisnis. Sebagai tambahan, pada kalimat (j) juga ditemukan kesalahan karena ketiadaan tanda koma untuk memisahkan anak kalimat yang mendahului induk kalimat dan penggunaan preposisi yang kurang tepat. Tanda koma tidak dipakai untuk memisahkan anak kalimat dari induk kalimat jika anak kalimat itu mengiringi induk kalimat (Doyin, 2010:36). Preposisi tentang sebaiknya diganti dengan dalam.

Kalimat (g), (h), (i), dan (j) dapat diperbaiki menjadi kalimat berikut.

(g.1) Makanan cepat saji adalah makanan langsung menjadi pembelian seperti makanan di Mc. Donald, di KFC, di Pizza Hut.

(h.1)Berdasarkan data data kepolisian RI pada tahun 1980, ditemukan fakta bahwa 50\% kecelakaan pengendara sepeda motor yang menimbulkan korban jiwa disebabkan oleh luka kepala.

(i.1)Beliau mempunyai satu tahi lalat yang besar di alis.

(j.1) Ibu saya tidak pandai dalam memasak makanan, tetapi dia sangat rajin dan pebisnis yang pintar.

Ketidaktepatan pemilihan kata yang kelima dilakukan oleh mahasiswa dari Vietnam bernama Linh. Kesalahan tersebut ditemukan pada kalimat berikut.

(k) Saya senang sekali ketika kalian menarik tentang Kebudayaan Indonesia.

(l) Kalian perlu semoga kepada mempelai laki-laki dan perempuan apa? 
(m) Menurut penelitian, betakaroten pada buah salak sangat tinggi daripada mangga 5 kali lebih besar.

(n) Apakah kalian masih ada kesempatan untuk lihat upacara yang lain.

(o) Menurut penelitian, mendengarkan musik sampil belajar dapat meningkatkan efektifitas belajar.

(p) Saya mau deskripsi tentang botol air.

Konjungsi ketika pada kalimat (k) tidak tepat. Seharusnya, menggunakan konjungsi kalau/jika/apabila karena kalimat tersebut merupakan kalimat pengandaian. Kesalahan lain berupa kesalahan diksi dalam verba pasif. Verba menarik pada klausa kedua kalian menarik Kebudayaan Indonesia tidak tepat.Klausa tersebut dapat diperbaiki menjadi kalian tertarik Kebudayaan Indonesia.

Diksi dan susunan unsur pada kalimat (l) kurang tepat. Sebaiknya, diksi semoga diganti dengan berdoa.Kata perlu dalam kalimat tersebut harus dihilangkan agar efektif. Susunan unsur kalimatnya juga harus diubah atau diperbaiki.

Diksi sangat pada kalimat (m) kurang tepat karena disandingkan dengan daripada. Kalimat tersebut berbentuk komparatif sehingga diksi yang tepat adalah lebih, bukan sangat.

Seperti kesalahan yang dilakukan oleh Koharu, Linh juga menggunakan kata ada dalam kalimat (n) untuk menggantikan kata mempunyai. Sebaiknya, Linh menggunakan kata mempunyai.
Tambahan pula, kalimat tersebut merupakan kalimat tanya sehingga tanda baca akhirnya, seharusnya, berupa tanda tanya bukan tanda titik.

Diksi efektifitas pada kalimat (o) tidak tepat karena tidak baku. Diksi yang dipilih adalah diksi yang memenuhi syarat kebakuan. Selain itu, diksi yang digunakan harus tepat dan sesuai agar tidak ambigu dan bermakna ganda (Ayudia, Suryanto, dan Waluyo, 2016:40).Diksi tersebut tidak diserap dari kata effectivity, tetapi effectiveness. Padanan kata yang baku dari effectiveness adalah keefektifan. Kalau ingin tetap menggunakan diksi efektifitas, seharusnya menggunakan kata bakunya,yaitu efektivitas.

Diksi deskripsi tidak tepat digunakan sebagai predikat dalam kalimat (p). Hal itu karena deskripsi merupakan nomina. Kalimat tersebut memerlukan predikat berupa verba. Diksi yang tepat untuk menggantikannya adalah mendeskripsikan. Preposisi tentang perlu dihilangkan agar kalimat tersebut lebih efektif.

(k.1) Saya senang sekali ketika kalian menarik tentang Kebudayaan Indonesia.

(l.1) Kalian berdoa/berharap apa kepada mempelai laki-laki dan perempuan?

(m.1) Menurut penelitian, betakaroten pada buah salak sangat tinggi daripada mangga 5 kali lebih besar.

(n.1) Apakah kalian masih mempunyai kesempatan untuk lihat upacara yang lain?

60 | Jurnal Kredo 


\section{(o.1) Menurut penelitian, mendengarkan musik sambil belajar dapat meningkatkan efektivitas belajar.}

\section{(p.1) Saya mau mendeskripsikan botol air.}

Kesalahan diksi yang keenam dilakukan oleh My dari Vietnam. Kesalahan tersebut hanya dijumpai pada kalimat berikut.

(q) Dengan saya, dia sangat ganteng.

Penggunaan diksi dengan pada kalimat (q) tidak tepat. Seharusnya, diksi dengan diganti dengan menurut. Dengan begitu, kalimat tersebut menjadi kalimat efektif dan mudah dipahami. Apabila kata dengan masih digunakan, bisa menimbulkan makna bahwa kalau tidak dengan My, subjek dia tidak ganteng lagi atau biasa-biasa saja. Perbaikannya sebagai berikut.

(q.1) Menurut saya, dia sangat ganteng.

Kesalahan diksi ketujuh dilakukan oleh Mei-Mei dari China. Kesalahan tersebut terdapat kalimat berikut.

(r) Potong kecil-kecil, lebih nyaman untuk makan

(s) Setelah selesai, dapat taburi dengan irisan daun bawang, sebagai dekorasi dan tidak berminyak.

(t) Masukkan rempah-rempah diasinkan 10 menit, dapat menghilangkan bau ikan dan lebih lezat. (u) belajar bahasa mandarin ternyata bermanfaat bagi pengembangan otak besar,

(v) cha De Lin melakukan penelitian terhadap IQ anak dari lima negara yakni: inggris, Amerika, Perancis, Jerman-barat, dan Eropa nilai rata-ratanya 100 , sedangkan IQ rata-rata anakanak Jepang ialah 111, sebabnya ialah anak-anak Jepang telah mempelajari huruf kanji (aksara mandarin).

(w) Pada bulan Mei 1982 Pakar Psychology Dr cha De Lin di majalah yang tersohor di seluruh dunia, mempublikasikan sebuah yang artikel yang menggegerkan dunia

(x) Oleh karena itu marilah belajar bahasa mandarin, karena dengan bahasa mandarin kita dapat berkomunikasi dengan lebih banyak orang di seluruh dunia dan meningkatkan.

Pada klausa kedua kalimat (r) terdapat diksi nyaman dan makan. Diksi nyaman kurang tepat digunakan dalam klausa tersebut. Diksi yang lebih tepat adalah mudah. Selain itu, diksimakanjuga tidak tepat digunakan dalam klausa kedua. Verba makan pada klausa (2) sebaiknya diganti dengan dimakan karena berbentuk pasif. Kalimat (r) perlu ditambahi konjungsi yang menyatakan tujuan untuk menghubungkan dua klausa. Konjungsi yang tepat adalah agar atau supaya.

Diksi taburi dan dekorasi kurang tepat digunakan di dalam kalimat (s). Seharusnya, diksi taburi 
diganti dengan ditaburi dan diksi dekorasi diganti dengan hiasan.

Pada kalimat (t) ditemukan urutan yang tidak paralel, yaitu menghilangkan bau ikan dan lebih lezat. Agar efektif, perlu ditambah satu verba lagi, misalnya verba menjadikan. Dalam kalimat atau tuturan yang berisi perincian, satuansatuan dalam perincian itu akan lebih efektif jika diungkapkan dalam bentuk yang sejajar. Jika perincian satu diungkapkan dalam bentuk kata kerja, perincian yang lain pun sebaiknya diungkapkan dalam bentuk kata kerja juga. Demikian pula jika perincian atu diungkapkan dalam bentuk kata benda, perincian yang lain hendaknya diungkapkan dalam bentuk kata benda (Tim Penyusun Buku Ajar, 1998:100). Kalimat (t) tidak efektif karena ada pelesapan konjungsi dan preposisi. Sebaiknya, kalimat tersebut ditambah dengan konjungsi dan dan preposisi untuk.

Pada kalimat (u) terdapat diksi pengembangan. Sebaiknya, diksi pengembangan yang berarti proses mengembangkan diganti dengan perkembangan yang berarti perihal berkembang. Dengan demikian, kalimat tersebut menjadi efektif.

Pada kalimat (v) dijumpai diksi sebabnya yang penggunaanya kurang tepat. Dalam KBBI Luring Edisi IV tidak ditemukan kata sebabnya. Sebaiknya, diksi tersebut diganti dengan penyebabnya.

Pada kalimat (w) dijumpa dua penggunaan diksi yang salah karena menggunakan istilah asing dan peluluhan yang salah. Diksi phsycology masih berbentuk bahasa Inggris sehingga perlu diindonesiakan menjadi psikologi, sedangkan mempublikasikan mengalami peluluhan pada fonem $/ p /$ sehingga menjadi memublikasikan.

Kalimat (x) termasuk kalimat yang tidak lengkap karena kurang objek pada verba transitif meningkatkan. Kalimat tersebut perlu ditambahi objek yang ditingkatkan, misalnya jumlah teman.

Perbaikan kalimat (r), (s), (t), (u), (v), (w), dan (x) sebagai berikut.

(r.1) Potong kecil-kecil agar lebih mudah untuk dimakan!

(s.1) Setelah selesai, dapat ditaburi dengan irisan daun bawang sebagai hiasan agar tidak berminyak.

(t.1) Masukkan rempah-rempah dan diasinkan 10 menit untuk menghilangkan bau ikan dan menjadikannya lebih lezat.

(u.1) belajar bahasa mandarin ternyata bermanfaat bagi pengembangan otak besar,

(v.1) cha De Lin melakukan penelitian terhadap IQ anak dari lima negara yakni: inggris, Amerika, Perancis, Jerman-barat, dan Eropa nilai rata-ratanya 100, sedangkan IQ rata-rata anakanak Jepang ialah 111, penyebabnya ialah anak-anak Jepang telah mempelajari huruf kanji (aksara mandarin).

(w.1) Pada bulan Mei 1982 Pakar Psikologi Dr cha De Lin di majalah yang tersohor di seluruh dunia, memublikasikan sebuah yang artikel yang menggegerkan dunia

(x.1) Oleh karena itu marilah belajar bahasa mandarin, karena dengan 
bahasa mandarin kita dapat berkomunikasi dengan lebih banyak orang di seluruh dunia dan meningkatkan jumlah teman.

Kesalahan diksi selanjutnya, yaitu yang kedelapan, dilakukan oleh Evan dari Timor Leste. Kesalahan tersebut dapat dilihat pada kalimat berikut.

(y) Sekian dulu, Sally, saya tunggu pembalasan dari kamu, salam dari Ibu Simpson.

(z) Salam dari Ibu Simpson, Sally, saya sehat-sehat dan saya sangat senang karena sally udah membaca email saya dan Terima kasih sudah undang saya secara tidak langsung Kalau saya berlibur di Indonesia mungkin saya akan ikut ke upacara akad nikah, dan saya bisa tahu tentang upacara akad nikah yang ada di jawa menurut adat orang jawa dan proses-proses yang menjalan upacara akad nikah, karena pernikahan yang ada di Jawa tidak seperti pernikahan yang ada di Bali dan propinsi-propinsi yang lain. mungkin tahun depan saya akan ke Indonesia untuk mengunjungi wisata-wisata yang ada disana, jika ada ada upacara akad nikah, kau bisa membawah ke acara itu.

Diksi pembalasan pada kalimat (y) tidak tepat digunakan karena bermakna proses membalas. Seharusnya, kata yang digunakan adalah balasan yang bermakna hasil dari membalas.

Berdasarkan kekompleksan ide pokoknya, kalimat (z) merupakan sebuah paragraf. Karena tanda bacanya tidak digunakan dengan benar, paragraf tersebut hanya menjadi satu kalimat. Sebenarnya, paragraf tersebut bisa diuraikan dengan menambahkan tanda baca akhir di tiap ide pokok. Kesalahan diksi pada tiap kalimat dalam paragraf tersebut berupa (a) penggunaan kata tidak baku, (b) penggunaan istilah asing, (c) kata dasar tidak berimbuhan, (d) kesalahan pemilihan diksi, dan (e) penulisan kata depan di-. Penggunaan kata baku ditemukan pada kata udah dan propinsi. Penggunaan istilah asing ditemukan pada kata email. Kata email perlu diterjemahkan menjadi surat elektronik (surel) atau pos-el. Penggunaan kata dasar tidak berimbuhan pada kalimat aktif ditemukan pada kata undang. Seharusnya, digunakan kata mengundang. Kesalahan pemilihan diksi ditemukan pada kata menjalan. Seharusnya, kata tersebut diganti dengan dijalankan, bukan menjalan atau menjalankan. Adapun kesalahan selanjutnya adalah ketiadaan objek pada verba membawa (terdapat tipologipada verba membawah). Pada verba tersebut perlu ditambahi objek saya. Kesalahan terakhir pada kalimat (z) adalah penulisan kata depan $d i$ - yang seharusnya dipisah dari kata yang mengikutinya. Penulisan yang tepat adalah di sana, bukan disana.

Perbaikan kalimat-kalimat tersebut sebagai berikut.

(y.1) Sekian dulu, Sally, saya tunggu balasan dari kamu, salam dari Ibu Simpson. 
(z.1) Salam dari Ibu Simpson. Sally, saya sehat-sehat dan sangat senang karena Sally sudah membaca pos-el saya. Terima kasih sudah mengundang saya secara tidak langsung. Kalau berlibur di Indonesia, mungkin saya akan ikut ke upacara akad nikah sehingga bisa tahu tentang upacara akad nikah yang ada di Jawa menurut adat orang jawa dan proses-proses yang dijalankan. Pernikahan yang ada di Jawa tidak seperti pernikahan yang ada di Bali dan provinsi-provinsi yang lain. mungkin tahun depan saya akan ke Indonesia untuk mengunjungi wisata-wisata yang ada di sana. Jika ada upacara akad nikah, kau bisa membawa saya ke acara itu.

Kesalahan diksi kesembilan dilakukan oleh Uswatee dari Thailand. Pembahasannya sebagai berikut.

\section{(a.2) Beli kain kaos dan pilih kain yang anda sukai}

(b.2) Sebelumnya, harus ukur badan yang ingin menjahit atau ukur pada baju.

(c.2) Oleh itu, marilah minum obat dengan air putih karena air putih bebas dari kandungan bahan kimia sehingga tidak menimbulkan kontraksi.

Pada kalimat (a.2) terdapat diksi kaos. Kata kaos tidak baku dalam bahasa Indonesia. Seharusnya, kata kaos diganti dengan kaus.

Kalimat (b.2) tidak logis karena diksi yang digunakan tidak tepat. Katabadan adalah benda mati yang tidak bisa menjahit. Seharusnya, verba menjahit diganti dengan verba dijahitkan karena badan adalah objek yang dikenai pekerjaan. Preposisi pada pada kalimat tersebut perlu dihilangkan agar efektif.

Kalimat (b.3) terdiri atas tiga klausa, yaitu (1) marilah minum obat dengan air putih, (2) air putih bebas dari kandungan bahan kimia, dan (3) tidak menimbulkan kontraksi. Dalam kalimat tersebut juga terdapat tiga konjungsi, yaitu oleh itu, karena, dan sehingga. Konjungsi oleh itu tidak lazim dalam bahasa Indonesia, tetapi lazim dalam bahasa Melayu. Konjungsi antarkalimat yang tepat dalam bahasa Indonesia adalah oleh karena itu. Sebaiknya, konjungsi sehingga diganti dengan konjungsi dan agar lebih efektif dan tidak ganda konjungsi sebab-akibat dalam satu kalimat. Diksi kontraksiyang bermakna pengerutanjuga tidak tepat digunakan dalam kalimat tersebut. Diksi yang sesuai dengan konteks kalimat tersebut adalah kontradiksi yang bermakna pertentangan. .

Perbaikan kalimat-kalimat tersebut sebagai berikut.

(a.2.1) Beli kain kaus dan pilih kain yang anda sukai.

(b.2.1) Sebelumnya, harus ukur badan yang ingin dijahitkan atau ukur baju.

(c.2.1) Oleh karena itu, marilah minum obat dengan air putih karena air putih bebas dari kandungan bahan kimia dan tidak menimbulkan kontradiksi!

Kesalahan diksi kesepuluh dilakukan oleh Adrian dari Mexico. Kesalahan tersebut 
dapat dijumpai pada kalimat berikut.

(d.2) Ini adalah kertas meja kayu dengan logam

\section{(e.2) Kayu meja ada warna putih dan punya nomor 5}

\section{(f.2) Kursi ada warna biru}

Kalimat (d.2) ambigu karena diksinya kurang tepat dan tanda bacanyatidak ada.Maksud kalimat tersebut memiliki dua kemungkinan. Kemungkinan pertamaAdrian hendak menunjukkan kertas dan meja yang terbuat dari kayu dan logam. Namun, karena tanda bacanya tidak ada, kalimatnya jadi membingungkan pembaca.Kemungkinan kedua Adrian hendak menunjuk kertas, meja, kayu, dan logam yang ada di hadapannya. Konjungsi dengan bisa diganti dengan dan yang berfungsi untuk menghubungkan. Dengan demikian, bila diksi yang digunakan tidak tepat, akan menyebabkaninformasi atau pesan yang ingin disampaikan kepada pembaca tidak tersampaikandan bahkan menyebabkan interpretasi berlainan bagi pembaca (Barsyah, 2014).

Diksi ada pada kalimat (e.2) dan (f.2) kurang tepat digunakan. Dalam Kamus Besar Bahasa Indonesia kata ada memang bisa diartikan mempunyai, tetapi kurang lazim digunakan dalam bahasa Indonesia ragam tulis. Sebaiknya, kata ada diganti dengan kata mempunyai.Kata mempunyai bisa diefektifkan dengan cara menggantinya dengan imbuhan berSelain dengan mengganti kata ada dengan mempunyai, kedua kalimat tersebut dapat diperbaiki dengan cara menyederhanakan unsur-unsur pembentuknya. Kesalahan diksi kalimat (e.2) juga disebabkan oleh penggunaan susunan frasa yang terbalik. Seharusnya, frasa digunakan adalah meja kayu yang bermakna meja yang terbuat dari kayu, bukan kayu meja karena susunan frasa bahasa Indonesia adalah Diterangkan-Menerangkan.

(d.2.1) Ini kertas dan meja yang terbuat dari kayu dan logam.

(e.2.1) Meja kayu berwarna putih dan berangka 5

\section{(f.2.1) Kursi berwarna biru}

Kesalahan diksi terakhir, yaitu kesebelas, dilakukan oleh Ola dari Polandia. Kesalahan tersebut berupa penggunaan diksi yang kurang tepat dan penghilangan preposisi. Kesalahan diksi Ola dapat dilihat pada kalimat berikut.

(g.2) Saya akan deskripsi buku berjudul "Cube Libre" ditulis Joeur Sqnchez.

Diksi deskripsi tidak tepat digunakan sebagai predikat dalam kalimat (g.2)karena predikat yang dibutuhkan adalah verba, bukan nomina. Seharusnya, predikat yang digunakan adalah verba mendeskripsikan. Kesalahan lain dalam kalimat tersebut adalahpreposisi yang dihilangkan. Preposisi tersebutadalah yang sebelum klausa ditulis oleh Joeur Sqnchez. Kalimat tersebut dapat diperbaiki menjadikalimat berikut.

\section{(g.2.1) Saya akan mendeskripsikan buku berjudul "Cube Libre" yang ditulis Joeur Sqnchez.}


Kesalahan diksi dapat dijabarkan menjadi beberapa tipe. Dalam penelitian ditunjukkan bahwa kesalahan diksi dalam kalimat mahasiswa BIPA berupa (1) 22 pemilihan diksi yang kurang atau tidak tepat, (2) 6 kesalahan penggunaan verba aktif dan pasif, (3) 3 penggunaan istilah asing, (4) 2 penggunaan kata ganti yang kurang atau tidak tepat, (5) 5 penggunaan konjungsi yang tidak tepat, (6) 3 kelebihan kata atau pengulangan kata, (7) 5 penggunaan kata tidak baku, (8) 1 ketidakparalelan, (9) 4 penggunaan preposisi yang tidak tepat, dan (10) 2 susunanfrasa yang terbalik.

Berikut grafik persebaran sepuluh faktor penyebab kesalahan diksi.

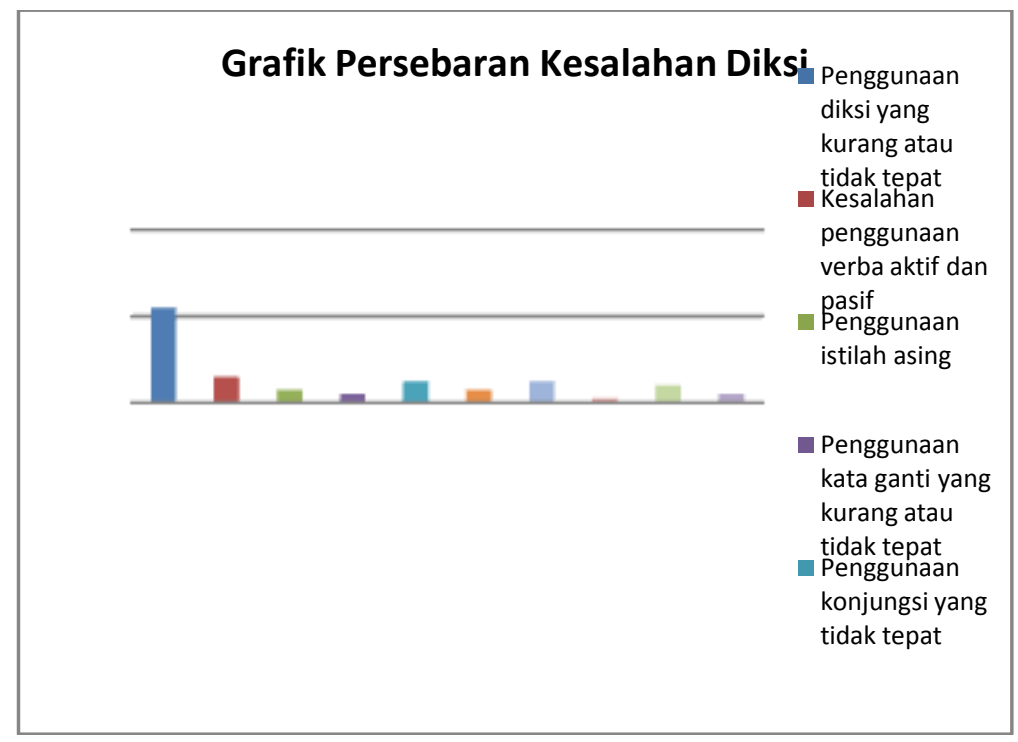

\section{Hubungan \\ Penguasaan Kosakatadengan Kesalahan Diksi}

Kesalahan diksi yang dilakukan oleh para mahasiswa BIPA dipengaruhi oleh beberapa faktor. Salah satunya adalah penguasaan kosakata mahasiswa. Kosakata adalah perbendaharaan kata. Kosakata sebagai salah satu materi pembelajaran bahasa Indonesia di sekolah menempati peran yang sangat penting sebagai dasar penguasaan siswa terhadap penguasaan dalam materi mata pelajaran bahasa Indonesia dan penguasaan mata pelajaran lainnya. Penguasaan kosakata akan mempengaruhi cara berpikir dan kreativitas siswa dalam proses pembelajaran bahasa sehingga penguasaan kosakata dapat menentukan kualitas seorang siswa dalam berbahasa (Kasno, 2004:1).

Berkaitan dengan komunikasi, Alqahtani (2015:22) menjelaskan penguasaan kosakata sering dianggap sebagai hal yang penting bagi pelajar bahasa kedua karenakosakata yang terbatas dalam bahasa kedua dapat menghambat keberhasilan berkomunikasi. Hal tersebut dikuatkan oleh Robihim (2008:189) bahwa seseorang tidak akan dapat berbahasa dengan baik, baik dalam berbahasa lisan maupun

66 | Jurnal Kredo 
tulisan tanpa menguasai kosakata. Penguasaan kosakata juga berkaitan dengan pemahaman bahasa seseorang.

Belajar kosakata merupakan proses yang berkelanjutan mulai dari menghadapi kata-kata baru dalam konteks yang bermakna dan dipahami. Siswa harus memperoleh jumlah kata yang memadai dan harus tahu menggunakan kata tersebut dengan benar dalam rangka berkomunikasi dengan baik dalam bahasa asing (Efendi, 2013:78). Efendi menambahkan bahwa sebenarnya para siswa memahami pentingnyapenguasaan kosakata, akan tetapi sebagian besar siswa menganggap proses penguasaan kosakata merupakan hal yang membosankan, karena mereka harus menghafal kata-kata asing dan ejaan. Kosakata tidak boleh diabaikan oleh siapa saja yang belajar bahasa. Minimnya penguasaan kosakata siswa adalah masalah serius yang perlu diperhatikan dan dicarikan solusi bagi mereka untuk menemukan cara yang tepat dalam meningkatkan penguasaan kosakata (Hanifia, 2013:82). Peran kosakata sangat penting dalam belajar bahasa asing, penguasaan harus dipastikan dan dikembangkan. Penguasaan kosakata yang terbatas akan berdampak pada kesulitan dalam belajar keterampilan bahasa (Azar, 2012:253). Penguasaan kosakata sangat diperlukan dalam pembelajaran bahasa sebagai dasar menguasai empat keterampilan bahasa yaitu menulis, menyimak, membaca, dan berbicara. Penguasaan kosakata juga memengaruhi kefasihan seseorang dalam berkomunikasi, dengan kata lain, penguasaan kosakata yang banyak dapat membuat seseorang berkomunikasi dengan baik.

Mahasiswa mengakui bahwa penguasaan kosakatanya sangat rendah. Penguasaan kosakata yang rendah dan kesalahan memahami arti kata yang sama dengan arti yang berbeda memengaruhi kemampuannya dalam menulis kalimat. Hal itu berakibat pada kesalahan penggunaan diksi. Pengajar BIPA membenarkan bahwa banyaknya pilihan kata dan banyaknya kosakata yang belum dikuasai oleh mahasiswa membuat mereka kesulitan menuangkan gagasan melalui bahasa tulis.

$$
\text { Upaya peningkatan }
$$

penguasaan kosakata dapat dilakukan di dalam pembelajaran atau di luar pembelajaran. Dalam pembelajaran pengajar dapat menggunakan media pembelajaran BIPA. Media menjadi salah satu komponen yang penting dalam pembelajaran. Hal ini pernah dilakukan oleh Widiyanto (2017:120-143) dalam penelitiannya terhadap pelajar BIPA di Tunisia. Widiyanto menggunakan media wayang untuk memperkenalkan kosakata baru.

\section{SIMPULAN}

Berdasarkan penelitian yang telah dilakukan, diperoleh simpulan bahwa kesalahan diksi terbanyak terjadi pada penggunaan diksi yang kurang atau tidak tepat. Kesalahan tersebut disebabkan oleh kekurangmampuan mahasiswa BIPA dalam memahami bentuk dan makna kata setelah mengalami proses gramatikal, yakni afiksasi, reduplikasi, atau komposisi. Selain itu, mahasiswa BIPA juga belum sepenuhnya memahami kata baku dan tidak baku, perbedaan verba aktif 
dan pasif, serta menggunakan kata ganti, kata hubung, dan kata depan.

Penguasaan kosakata adalah modal utama dalam belajar berbahasa. Jumlah kosakata bahasa Indonesia yang dikuasai oleh pembelajar sangat memengaruhi kemampuan berbahasanya. Apabila pembelajar BIPA menguasai banyak kosakata bahasa Indonesia, dia akan bisa menggunakan diksi dengan tepat untuk menulis kalimat. Jadi, makin banyak kosakata yang dikuasai oleh pembelajar, makin baik pula kemampuannya memilih kata untuk dituliskan menjadi kalimat.

Hasil penelitian ini dapat dijadikan sebagai rujukan bagi peneliti lain untuk menyempurnakan penelitiannya. Selain itu, hendaknya mahasiswa BIPA selalu meningkatkan penguasaan kosakata bahasa Indonesianya sebagai modal baku dalam menyusun sebuah kalimat. Hal itu bisa dilakukan dengan cara sering membaca bahan bacaan berbahasa Indonesia dan menuliskannya kembali. Dengan begitu, mahasiswa diharapkan selalu meningkatkan jumlah kosakatanya agar kesalahan diksinya bisa diatasi. Peningkatan penguasaan kosakata dapat dilakukan dengan media pembelajaran.

\section{DAFTAR PUSTAKA}

Alqahtani, Mofareh. (2015). The Importance of Vocabulary in Language Learning and How to be Taugh. International Journal of Teaching and Education, 3 (2), 21-34.

Arifin, E. Zainal dan S. Amran Tasai. (2010). Cermat Berbahasa Indonesia untuk Perguruan Tinggi. Jakarta: Akapress.

Ayudia, Edi Suryanto, dan Budhi Waluyo. (2016). Analisis Kesalahan Penggunaan Bahasa Indonesia dalam Laporan Hasil Observasi pada Siswa SMP. BASASTRA Jurnal Penelitian Bahasa, Sastra Indonesia dan Pengajarannya, 4 (1), ISSN I2302-6405

Azar, Ali Sorayaie. (2012). The Effect of Games on EFL Learners' Vocabulary Learning Strategies. International Journal of Basic and Applied Science, 1 (2), 252-256.

Barsyah, Akbar. (2014). Analisis Kesalahan Diksi dalam Rubrik Berita Finance Surat Kabar Tribun Batam. Skripsi. Tnjungpinang: Fakultas Keguruan dan Ilmu PendidikanUniversitas Maritim Raja Ali Haji.

Brown, H. Douglas (1994). Principles of Language Learning and Teaching. New Jersey: Prentice Hall Regents.

Doyin, Mukh. (2010). Membaca EYD. Semarang: Bandung Institute. 
Dulay, H., Burt, M. \& Krashen, S.(1982). Language Two. New York: Oxford University Press.

Efendi, Erfan. (2013). The Use of Games to Improve Vocabulary Mastery.JP3, 1 (1), 78-84.

Elviza, Yulia, Emidar, dan Noveria, Ena. (2013). Peningkatan Penguasaan Kosakata melalui Teknik Permainan Teka-Teki Silang di Kelas VII A SMPN 2 Sungai Penuh.Jurnal Pendidikan Bahasa dan Sastra Indonesia, 1 (2), 469-476.

Finoza, Lamuddin. (2010). Komposisi Bahasa Indonesia. Jakarta: Diksi Insan Mulia.

Furqon, Fajar. (2013). Correlation Between Students' Vocabulary Mastery and Their Reading Comprehension. Journal of English and Education, 1 (1), 68-80.

Hanifia, Fika Nurul. (2013). The Use of Vocabulary Journal in Enriching Students' Vocabulary Mastery and The Students' Attitudes Toward Its Use.The Journal English and Education, 1 (1), 81-88.

Iskandarwassid dan Sunendar, Dadang. (2013). Strategi Pembelajaran Bahasa. Bandung: Remaja Rosdakarya Offset.

Kasno. (2004).Kamus sebagai Sumber Rujukan dan Pengajaran Kosakata.Jakarta: Pusat Bahasa.

Keraf, Gorys. (2009). Diksi dan Gaya Bahasa. Jakarta: Gramedia Pustaka Utama.

Kusmiatun, Ari. (2016). Mengenal BIPA (Bahasa Indonesia bagi Penutur Asing) dan Pembelajarannya. Yogyakarta: K-Media.

Mahmud, H. (2011). Metode Penelitian Pendidikan. Bandung: Pustaka Setia.

Muliastuti, Liliana. (2010). Pengembangan Materi Ajar Bahasa Indonesia Bagi Penutur Asing (BIPA). Disampaikan dalam Konferensi Internasional Pengajaran Bahasa Indonesia Bagi Penutur Asing, 29-31 Juli 2010 di Universitas Indonesia.

Nasution, S. (1992). Metode Penelitian Naturalistik-Kualitatif. Bandung: Tarsito.

Pusvita, Winda Dewi. (2017). Dampak Penguasaan Kosakata terhadap Bahasa Tulis Pembelajar BIPA Tingkat Dasar (Studi Kasus di UPT BahasaUniversitas Sebelas Maret). Tesis. Surakarta: PBI FKIP UNS.

Robihim.(2008). Analisis Metode Belajar Kosakata.Jurnal Lingua Cultura, 2 (2), 188-203.

HUBUNGAN PENGUASAAN KOSAKATA DENGAN KESALAHAN DIKSI | 69 
Sanjaya, Wina. (2006). Strategi Pembelajaran Berorientasi Standar Proses Pendidikan. Jakarta: Kencana Prenada Media.

Schmitt, Norbert dan McCarthy, Michael.(1997). Vocabulary: Description, Acquisition and Pedagogy. United Kingdom: Cambridge University Press. Sumarwati. (2015). Menulis Karya Ilmiah dalam Bahasa Indonesia. Surakarta: UNS Press.

Sutopo, H. B. (2006). Metodologi Penelitian Kualitatif Dasar Teori danTerapannya dalam Penelitian. Surakarta: Universitas Sebelas Maret.

Tim Penyusun Buku Ajar. (1998). Bahasa Indonesia untuk Mahasiswa. Semarang: Badan Penerbit Undip.

Tim Pusat Bahasa. (2006). Buku Praktis Bahasa Indonesia Jilid I. Jakarta Timur: Pusat Bahasa.

Widianto, Eko. (2017).Media Wayang Mini dalam Pembelajaran Keterampilan Berbicara bagi Pemelajar BIPA A1 Universitas Ezzitouna Tunisia. Jurnal Kredo, Vol. 1 (1), hlm. 120-143.

Yule, George. (2014). Kajian Bahasa. Yogyakarta: Pustaka Pelajar. 